\title{
Analysis of additivity and synergism in the anti-plasmodial effect of purified compounds from plant extracts
}

\author{
Eric Deharo ${ }^{1,2^{*}}$, Hagai Ginsburg ${ }^{3}$
}

\begin{abstract}
In the search for antimalarials from ethnobotanical origin, plant extracts are chemically fractionated and biological tests guide the isolation of pure active compounds. To establish the responsibility of isolated active compound(s) to the whole antiplasmodial activity of a crude extract, the literature in this field was scanned and results were analysed quantitatively to find the contribution of the pure compound to the activity of the whole extract. It was found that, generally, the activity of isolated molecules could not account on their own for the activity of the crude extract. It is suggested that future research should take into account the "drugs beside the drug", looking for those products (otherwise discarded along the fractionation process) able to boost the activity of isolated active compounds.
\end{abstract}

\section{Introduction}

In the search for anti-malarial activity of plants traditionally used against fevers, collected plants are first submitted to an extraction process with polar or apolar solvents. Ideally, the extracts are then tested against erythrocytic stages of Plasmodium falciparum in vitro to validate anti-plasmodial activity. Classically, when biological tests identify significant activity, crude extracts are submitted to a bioguided fractionation procedure, aiming to isolate the active compound(s). For that purpose, several sequential extractions with solvents of diverse polarities are performed, and purified fractions are submitted to anti-plasmodial tests and to chemical identification. Frequently, many promising extracts are discarded because the anti-plasmodial activity disappears along the fractionation process. The failure to isolate active constituents from active extracts may be due to the lability/instability of the active compounds that are degraded during the extraction process. Sometimes, the loss of activity is due to the fact that the compounds display their activity only when they interact in the crude extract. Such compounds will be lost for further

\footnotetext{
* Correspondence: ericdeharo@gmail.com

'Laboratoire de Pharmacochimie des Substances Naturelles et Pharmacophores Redox, UMR 152, UPS, Université de Toulouse, 118 Route de Narbonne, F-31062 Toulouse cedex 9, France

Full list of author information is available at the end of the article
}

development unless their interactions can be examined. In order to evaluate such interactions, mostly synergistic, it is necessary to know the inhibitory activity of the crude extract and the purified fractions (i.e., their $\mathrm{IC}_{50}$ values) and the yields of extraction of the purified compounds to allow calculation of their absolute quantitative prevalence in the extract. Unfortunately, in most cases, when plants are extracted and fractionated, the activity of the crude extract is not determined and the yields are not reported or not determined altogether. This is the case of hundreds of thousands of purified fractions of natural extracts that have been evaluated by cell-based inhibition tests.

To determine the quantitative contribution of the pure compounds to the activity of a crude extract, data from the literature were compiled selecting those publications in which the activities of the crude extracts and of the purified compounds (and their yields) were reported. To calculate the contribution of the pure active compound to the activity of the extract, the respective $\mathrm{IC}_{50}$ values and the yield of the purified compound are used. Data are shown in table 1 .

The equation describing the relationship between concentration and $\mathrm{IC}_{50}$ is:

$\mathrm{f}=\max -(\max -\mathrm{min}) /\left(1+\mathrm{x} / \mathrm{EC}_{50}\right)^{\text {slope }}$ where " $\mathrm{f}$ " is the inhibitory effect. The $\mathrm{EC}_{50}$ is the $\mathrm{IC}_{50}$ of the isolated compound and " $\mathrm{x}$ " is the yield-dependent calculated concentration of 
Table 1 Compilation of data from the literature on the anti-plasmodial effects of plant extracts and their fractionated active compounds. CS and CR are chloroquine-sensitive and -resistant strains respectively

\begin{tabular}{|c|c|c|c|c|c|c|c|c|c|}
\hline Plant Species & Family & $\begin{array}{l}\text { Parasite } \\
\text { strain }\end{array}$ & $\begin{array}{l}\text { Extract } \\
I C_{50} \\
\mu \mathrm{g} / \mathrm{ml}\end{array}$ & $\begin{array}{l}\text { Most active } \\
\text { compounds* }\end{array}$ & $\begin{array}{l}\text { Compounds } \\
\mathrm{IC}_{50} \mu \mathrm{g} / \mathrm{ml}\end{array}$ & $\begin{array}{c}\text { Yield } \\
\%\end{array}$ & $\begin{array}{c}\% \text { of } \\
\text { active } \\
\text { comp of } \\
\text { extract } \\
I_{50}\end{array}$ & $\begin{array}{c}\text { Contribution of } \\
\text { active } \\
\text { compound to } \\
\text { extract inhib \% }\end{array}$ & ref \# \\
\hline $\begin{array}{l}\text { Alstonia macrophylla } \\
\text { Wall. }\end{array}$ & Apocynaceae & $P f \mathrm{~K} 1 \mathrm{CR}$ & 5,7 & Macrocarpamine & 0,27 & 0,95 & 0,05 & 33,4 & 1 \\
\hline $\begin{array}{l}\text { Alstonia macrophylla } \\
\text { Wall. }\end{array}$ & Apocynaceae & Pf K1 CR & 5,7 & Villalstonine & 0,17 & 0,6 & 0,03 & 31,1 & 2 \\
\hline $\begin{array}{l}\text { Artemisia indica } \\
\text { Willd }\end{array}$ & Asteraceae & $P f \mathrm{~K} 1 \mathrm{CR}$ & 6,6 & Exigua flavanones & 4,6 & 0,15 & 0,01 & 0,4 & 3 \\
\hline $\begin{array}{l}\text { Brucea javanica L. } \\
\text { (Merr.) }\end{array}$ & Simaroubaceae & Pf K1 CR & 0,5 & Brucein & 0,005 & 0,002 & 0,00001 & 0,4 & 4 \\
\hline $\begin{array}{l}\text { Cryptolepis } \\
\text { sanguinolenta (Lindl.) }\end{array}$ & Apocynaceae & Pf K1 CR & 5,41 & Cryptolepine & 0,054 & 0,04 & 0,002 & 7,7 & 5 \\
\hline $\begin{array}{l}\text { Diospyros sanza- } \\
\text { minika A. Chevalier }\end{array}$ & Ebenaceae & Pf K1 CR & 0,8 & $\begin{array}{c}\text { 4-O-(3'-methylgalloyl) } \\
\text { norbergenin }\end{array}$ & 0,6 & 1,2 & 0,01 & 3,1 & 6 \\
\hline Erythrina fusca Lour. & Fabaceae & Pf $\mathrm{K} 1 \mathrm{CR}$ & 7,5 & Citflavanone & 5 & 0,1 & 0,01 & 0,4 & 7 \\
\hline Erythrina fusca Lour. & Fabaceae & Pf $\mathrm{K} 1 \mathrm{CR}$ & 7,5 & Lonchocarpol & 1,6 & 0,2 & 0,02 & 1,9 & 7 \\
\hline Erythrina fusca Lour. & Fabaceae & Pf K1 CR & 7,5 & 8-Prenyldaidzein & 3,9 & 0,0006 & 0,00005 & 0,002 & 7 \\
\hline Garcinia cowa L. & Clusiaceae & $\begin{array}{l}\text { Pf T9/ } \\
94 \mathrm{CS}\end{array}$ & 5 & 7-O-Methylgarcinone & 2,5 & 0,01 & 0,00030 & 0,02 & 8 \\
\hline Garcinia cowa L. & Clusiaceae & $\begin{array}{l}\text { Pf T9/ } \\
94 \mathrm{CS}\end{array}$ & 5 & Cowanin & 3 & 0,2 & 0,01 & 0,7 & 8 \\
\hline Garcinia cowa L. & Clusiaceae & $\begin{array}{l}\text { Pf T9/ } \\
94 \mathrm{CS}\end{array}$ & 5 & Cowanol & 1,6 & 0,5 & 0,03 & 3,1 & 8 \\
\hline Garcinia cowa L. & Clusiaceae & $\begin{array}{l}\text { Pf T9/ } \\
94 \mathrm{CS}\end{array}$ & 5 & Vowaxanthone & 1,5 & 0,4 & 0,02 & 2,6 & 8 \\
\hline Garcinia cowa L. & Clusiaceae & $\begin{array}{l}\text { Pf T9/ } \\
94 \mathrm{CS}\end{array}$ & 5 & b-Mangostin & 3 & 0,04 & 0,002 & 0,1 & 8 \\
\hline $\begin{array}{l}\text { Geissospermum } \\
\text { sericeum Miers }\end{array}$ & Apocynaceae & Pf K1 CR & 1,78 & Flavopereirine & 2,84 & 0,04 & 0,0008 & 0,06 & 9 \\
\hline $\begin{array}{l}\text { Gomphostemma } \\
\text { niveum Hook. f. }\end{array}$ & Lamiaceae & $\begin{array}{l}\text { Pf MR- } \\
\text { C02 CS }\end{array}$ & 9,7 & Gomphostenin & 38,2 & 0,5 & 0,05 & 0,3 & 10 \\
\hline $\begin{array}{l}\text { Gomphostemma } \\
\text { niveum Hook. f. }\end{array}$ & Lamiaceae & $\begin{array}{l}\text { Pf MR- } \\
\text { C02 CS }\end{array}$ & 3,4 & Gomphostenin-A & 3,4 & 24 & 0,83 & 39 & 10 \\
\hline $\begin{array}{l}\text { Guiera senegalensis J. } \\
\text { F. Gmel. }\end{array}$ & Combretaceae & Pf W2 CR & 4,45 & Harman (b-carboline) & 3,29 & 0,1 & 0,00445 & 0,3 & 11 \\
\hline $\begin{array}{l}\text { Holostylis reniformis } \\
\text { Duch. }\end{array}$ & Rubiaceae & $\begin{array}{c}\text { Pf } \\
\mathrm{BHz} 26 / \\
86 \mathrm{CR}\end{array}$ & 0,7 & Lignan & 0,12 & 0,4 & 0,003 & 4,6 & 12 \\
\hline $\begin{array}{l}\text { Holostylis reniformis } \\
\text { Duch. }\end{array}$ & Rubiaceae & $\begin{array}{c}\text { Pf } \mathrm{BHz} \\
\mathrm{CR}\end{array}$ & 0,7 & Lignan & 0,12 & 4,5 & 0,03 & 42 & 12 \\
\hline Nauclea orientalis L. & Rubiaceae & Pf D6 CS & 3 & Oleanolic acid & 4,6 & 0,07 & 0,002 & 0,08 & 13 \\
\hline Phyllanthus niruri L. & Euphorbiaceae & Pf CS & 1,3 & Terpenes & 1,3 & 0,1 & 0,002 & 0,3 & 14 \\
\hline $\begin{array}{l}\text { Piptadenia pervillei } \\
\text { Vatke (Entada } \\
\text { pervillei Vatke (R.Vig.) }\end{array}$ & Fabaceae & $\begin{array}{c}\text { Pf } \\
\text { MCF29 }\end{array}$ & 3,7 & Catechin derivatives & 0,4 & 0,03 & 0,001 & 0,6 & 15 \\
\hline $\begin{array}{l}\text { Piptadenia pervillei } \\
\text { Vatke (Entada } \\
\text { pervillei Vatke (R.Vig.) }\end{array}$ & Fabaceae & $\begin{array}{l}\text { Pf FCM29 } \\
\text { CR }\end{array}$ & 3,7 & Catechin derivatives & 0,3 & 0,1 & 0,004 & 2,4 & 15 \\
\hline $\begin{array}{l}\text { Pleiocarpa mutica } \\
\text { Benth. }\end{array}$ & Apocynaceae & Pf K1 CR & 16,7 & Pleiomutinine & 3,2 & 0,05 & 0,008 & 0,5 & 16 \\
\hline $\begin{array}{l}\text { Polyalthia debilis } \\
\text { (Piere) Finet \& } \\
\text { ganep }\end{array}$ & Annonaceae & Pf K1 CR & 1,35 & Bis-dehydroaporphine & 4,1 & 0,16 & 0,002 & 0,1 & 17 \\
\hline $\begin{array}{l}\text { Pothomorphe peltata } \\
\text { L. }\end{array}$ & Piperaceae & Pf K1 CR & 3,7 & 4-Nerolidylcatechol & 0,21 & 5,7 & 0,21 & 100 & 18 \\
\hline Quassia amara L. & Simaroubaceae & Pf W2 CR & 8,9 & Simalikalactone D & 0,005 & 0,001 & 0,0001 & 3,5 & 19 \\
\hline
\end{tabular}


Table 1 Compilation of data from the literature on the anti-plasmodial effects of plant extracts and their fractionated active compounds. CS and CR are chloroquine-sensitive and -resistant strains respectively (Continued)

\begin{tabular}{|c|c|c|c|c|c|c|c|c|c|}
\hline $\begin{array}{l}\text { Rhaphidophora } \\
\text { decursiva Schott }\end{array}$ & Araceae & Pf W2 CR & 6,8 & Polysyphorin & 0,37 & 0,00004 & 0,000003 & 0,001 & 20 \\
\hline $\begin{array}{l}\text { Rourea minor } \\
\text { (Gaertn.) Alston }\end{array}$ & Connaraceae & Pf W2 CR & 2 & Rourinoside (glycoside) & 1,2 & 4 & 0,08 & 12,5 & 21 \\
\hline $\begin{array}{l}\text { Stephania pierrei } \\
\text { Diels }\end{array}$ & Menispermaceae & $P f \mathrm{~W} 2 \mathrm{CR}$ & 3 & Asimilobine & 0,4 & 0,3 & 0,008 & 3,7 & 22 \\
\hline $\begin{array}{l}\text { Strychnos icaja } \\
\text { Baillon }\end{array}$ & Loganiaceae & Pf W2 CR & 0,3 & 18-hydroxyisosungucine & 0,09 & 0,03 & 0,0001 & 0,2 & 23 \\
\hline $\begin{array}{l}\text { Tapirira guianensis } \\
\text { Aubl. }\end{array}$ & Anacardiaceae & $\begin{array}{l}\text { Pf F32 } \\
\text { CR }\end{array}$ & 18 & $\begin{array}{c}\text { Cyclic alkyl polyol } \\
\text { derivatives }\end{array}$ & 4,7 & 2,7 & 0,49 & 18,9 & 24 \\
\hline $\begin{array}{l}\text { Tephrosia elata } \\
\text { Deflers }\end{array}$ & Fabaceae & Pf D6 CS & 8,4 & Elatadihydrochalcone & 2,8 & 0,2 & 0,02 & 1,1 & 25 \\
\hline $\begin{array}{l}\text { Tephrosia elata } \\
\text { Deflers }\end{array}$ & Fabaceae & Pf D6 CS & 8,4 & Obovatin & 4,9 & 0,05 & 0,004 & 0,2 & 25 \\
\hline $\begin{array}{l}\text { Tephrosia elata } \\
\text { Deflers }\end{array}$ & Fabaceae & Pf D6 CS & 8,4 & Obovatin methyl ether & 3,8 & 0,01 & 0,001 & 0,03 & 25 \\
\hline $\begin{array}{l}\text { Tephrosia elata } \\
\text { Deflers }\end{array}$ & Fabaceae & Pf D6 CS & 8,4 & Deguelin & 6,3 & 0,01 & 0,001 & 0,02 & 25 \\
\hline $\begin{array}{l}\text { Teucrium } \\
\text { ramosissimum } \\
\text { Desfontaines }\end{array}$ & Lamiaceae & Pf FCB1 & 2,7 & Homalomenol & 1,2 & 0,04 & 0,001 & 0,2 & 26 \\
\hline $\begin{array}{l}\text { Tithonia diversifolia } \\
\text { (Hemsl.) A. Gray }\end{array}$ & Asteraceae & $\begin{array}{l}\text { Pf FCA20 } \\
\text { Ghana } \\
\text { CS }\end{array}$ & 0,75 & Tagitinin (toxic) & 0,33 & 2,7 & 0,02 & 11,6 & 27 \\
\hline $\begin{array}{l}\text { Toddalia asiatica (L.) } \\
\text { Lam. }\end{array}$ & Rutaceae & $\begin{array}{l}\text { Pf K39 } \\
\text { CS }\end{array}$ & 22 & Coumarin & 16,2 & 2,0 & 0,44 & 5,3 & 28 \\
\hline Vernonia brasiliana L. & Asteraceae & $\begin{array}{c}\mathrm{Pf} \mathrm{BH}_{2} \\
\mathrm{CR}\end{array}$ & 50 & Lupeol & 25 & 0,4 & 0,22 & 1,7 & 29 \\
\hline $\begin{array}{l}\text { Vernoniopsis caudata } \\
\text { (Drake) Humbert }\end{array}$ & Asteraceae & $\begin{array}{l}\text { Pf FCB1 } \\
\text { CR }\end{array}$ & 1,6 & $\begin{array}{c}\text { Helenalin-[2-(1- } \\
\text { hydroxyethyl)acrylate] }\end{array}$ & 0,37 & 0,1 & 0,002 & 0,9 & 30 \\
\hline $\begin{array}{l}\text { Vernoniopsis caudata } \\
\text { (Drake) Humbert }\end{array}$ & Asteraceae & $\begin{array}{l}\text { Pf FCB1 } \\
\text { CR }\end{array}$ & 1,6 & $\begin{array}{c}\text { Helenalin-[(2- } \\
\text { hydroxyethyl-3-methyl) } \\
\text { acrylate] }\end{array}$ & 0,07 & 0,01 & 0,0002 & 0,5 & 30 \\
\hline $\begin{array}{l}\text { Vernoniopsis caudata } \\
\text { (Drake) Humbert }\end{array}$ & Asteraceae & $\begin{array}{l}\text { Pf FCB1 } \\
\text { CR }\end{array}$ & 1,6 & $\begin{array}{l}11 \mathrm{R}, 13- \\
\text { dihydrohelenalin-[2-(1- } \\
\text { hydroxyethyl)acrylate] }\end{array}$ & 0,15 & 0,02 & 0,0003 & 0,4 & 30 \\
\hline $\begin{array}{l}\text { Viola verecunda A. } \\
\text { Gray }\end{array}$ & Violaceae & $\begin{array}{l}\text { Pf FCB1 } \\
\text { CR }\end{array}$ & 25 & Epioleanolic acid & 0,18 & 0,03 & 0,01 & 7 & 31 \\
\hline $\begin{array}{l}\text { Zanthoxylum } \\
\text { rhoifolium Lam. }\end{array}$ & Rutaceae & $\begin{array}{l}\text { Pf FCB1 } \\
\text { CR }\end{array}$ & 10 & Nitidine & 1,8 & 6,00 & 0,6 & 50 & 32 \\
\hline $\begin{array}{l}\text { Zhumeria majdae } \\
\text { Rech.f. \& Wendelbo }\end{array}$ & Lamiaceae & $P f \mathrm{~W} 2 \mathrm{CR}$ & 7,5 & $\begin{array}{l}\text { 12,16-dideoxy } \\
\text { aegyptinone B }\end{array}$ & 1,4 & 0,6 & 0,05 & 6,2 & 33 \\
\hline
\end{tabular}

the compound at the $\mathrm{IC}_{50}$ of the extract. For the simplest case, the values are set such that $\max =100$ and max$\min =100$ and slope $=1$. The calculated partial effect of various compounds appears in the column captioned "\% of active compound at extract $\mathrm{IC}_{50}$ ".

Taking for example the case of the crude extract of Alstonia macrophylla and one of the most active compounds, macrocarpamine: one obtains a yield for macrocarpamine of $0.95 \%$ and it is straightforward to calculate that it is present in the extract at $0.054 \mathrm{mg}$ at the $\mathrm{IC}_{50}$ of the extract. Using the above equation one gets $\mathrm{f}=16.7$. Thus, the active compound contributes $16.7 / 50$ of the overall effect or $33.4 \%$. Another active compound, villalstonine, contributes $31.1 \%$ to the activity of the crude extract. Given the fact that there are other active compounds in the extract, it is possible to suggest that the effects of macrocarpamine and villalstonine are not synergized in the crude extract and that their effects are additive. In such cases it can be concluded that very few active compounds account for the activity of the crude extract.

However, in the case of Garcinia cowa and 7-0methylgarcinone, $0.0003 \mathrm{mg}$ of the compound was present in the extract at the $\mathrm{IC}_{50}$ of the extract. The calculated $\mathrm{f} \sim 0$ and the compound contributes only $0.02 \%$ to the anti-plasmodial activity of the crude extract. Since for all other purified compounds (cowanin, cowanol, cowaxanthone and b-mangostin) the contributions 
are $\leq 3.0 \%$, one is inclined to suggest that a strong synergism must occur between the components. Alternatively and quite unlikely, the extraction procedure destroys all the active compounds. In the extreme case of Pothomorphe peltata all the activity of the extract is accounted for by the activity of 4-nerolidylcatechol.

Inspection of the values that appear in the column captioned "\% of active compound at extract $\mathrm{IC}_{50}$ ", reveal that all cases can be subdivided in two groups. In one, the contribution of active compound to extract inhibition is $\geq \sim 20 \%$, while in the second the values center around $\sim 1 \%$ or significantly lower. Thus, in the second group considerable synergism between active compounds must exist in order to account for the activity of the extract, or the extraction procedure (quite unlikely) destroys the activity of all compounds.

Among the hundreds of articles describing the antiplasmodial activity of plant extracts (1,031 articles were retrieved from PubMed for the last 10 years), only very few included the activity of the whole extract and of the pure compounds and their respective yields of extraction. Nevertheless it is striking that for $90 \%$ of the plants compiled in Additional file 1 the anti-malarial activity of the purified compounds cannot account quantitatively with that of the crude extract. If indeed this observation reflects the reality of anti-malarial properties of plant extracts, may be research should be focused on the "drug beside the drug", looking for structures perhaps not exciting in the chemical point of view but that can revolutionize the treatment of malaria. Another natural consequence of this analysis is that evolution has provided not only bioactive metabolites that plants use to fight their foes, but has also mixed them in a very auspicious combination of compounds, which in some cases also work well in mammals. To achieve a similar combination even by systematic bioguided mixing is a very tedious, lengthy and expensive procedure. Why not learn from nature and optimize the use of plant extracts?

\section{Acknowledgements \\ Eric Deharo gratefully acknowledge the financial support of the Institut de Recherche pour le Développement. Publication charges for this article have been paid by the Institut de Recherche pour le Développement (IRD). This article has been published as part of Malaria Journal Volume 10 Supplement 1, 2011: Natural products for the control of malaria. The full contents of the supplement are available online at http://www.malariajournal.com/supplements/10/S1.}

\section{Author details}

${ }^{1}$ Laboratoire de Pharmacochimie des Substances Naturelles et

Pharmacophores Redox, UMR 152, UPS, Université de Toulouse, 118 Route de Narbonne, F-31062 Toulouse cedex 9, France. ${ }^{2}$ Institut de Recherche pour le Développement, UMR 152, Mission IRD casilla 18-1209 Lima, Peru. ${ }^{3}$ Department of Biological Chemistry, Institut of Life Sciences, The Hebrew University of Jerusalem, Jerusalem 91904, Israel.

\section{Competing interests}

The authors declare that they have no competing interests.

Published: 15 March 2011

\section{References}

1. Keawpradub N, Kirby GC, Steele JC, Houghton PJ: Antiplasmodial activity of extracts and alkaloids of three Alstonia species from Thailand. Planta Med 1999, 65:690-694.

2. Wright CW, Allen D, Phillipson JD, Kirby GC, Warhurst DC, Massiot G, Le Men-Olivier L: Alstonia species: are they effective in malaria treatment? J Ethnopharmacol 1993, 40:41-45.

3. Chanphen R, Thebtaranonth Y, Wanauppathamkul S, Yuthavong Y: Antimalarial principles from Artemisia indica. J Nat Prod 1998, 61:1146-1147.

4. O'Neill MJ, Bray DH, Boardman P, Chan KL, Phillipson JD, Warhurst DC, Peters W: Plants as sources of antimalarial drugs, Part 4: Activity of Brucea javanica fruits against chloroquine-resistant Plasmodium falciparum in vitro and against Plasmodium berghei in vivo. J Nat Prod 1987, 50:41-48.

5. Paulo A, Gomes ET, Steele J, Warhurst DC, Houghton PJ: Antiplasmodial activity of Cryptolepis sanguinolenta alkaloids from leaves and roots. Planta Med 2000, 66:30-34.

6. Tangmouo JG, Ho R, Matheeussen A, Lannang AM, Komguem J, Messi BB, Maes L, Hostettmann K: Antimalarial activity of extract and norbergenin derivatives from the stem bark of Diospyros sanza-minika A. Chevalier (Ebenaceae). Phytother Res 2010, 24:1676-1679.

7. Khaomek P, Ichino C, Ishiyama A, Sekiguchi H, Namatame M, Ruangrungsi N, Saifah E, Kiyohara H, Otoguro K, Omura S, Yamada H: In vitro antimalarial activity of prenylated flavonoids from Erythrina fusca. J Nat Med 2008, 62:217-220.

8. Likhitwitayawuid K, Phadungcharoen T, Krungkrai J: Antimalarial xanthones from Garcinia cowa. Planta Med 1998, 64:70-72.

9. Steele JC, Veitch NC, Kite GC, Simmonds MS, Warhurst DC: Indole and beta-carboline alkaloids from Geissospermum sericeum. J Nat Prod 2002, 65:85-88.

10. Sathe M, Kaushik MP: Gomphostenins: two new antimalarial compounds from the leaves of Gomphostemma niveum. Bioorg Med Chem Lett 2010, 20:1312-1314.

11. Fiot J, Sanon S, Azas N, Mahiou V, Jansen O, Angenot L, Balansard G, Ollivier E: Phytochemical and pharmacological study of roots and leaves of Guiera senegalensis J.F. Gmel (Combretaceae). J Ethnopharmacol 2006, 106:173-178.

12. de Andrade-Neto VF, da Silva T, Lopes LM, do Rosário VE, de Pilla Varotti F, Krettli AU: Antiplasmodial activity of aryltetralone lignans from Holostylis reniformis. Antimicrob Agents Chemother 2007, 51:2346-2350.

13. He ZD, Ma CY, Zhang HJ, Tan GT, Tamez P, Sydara K, Bouamanivong S, Southavong B, Soejarto DD, Pezzuto JM, Fong HH: Antimalarial constituents from Nauclea orientalis (L.) L. Chem. Biodivers 2005, 2:1378-1386.

14. Cimanga RK, Tona L, Luyindula N, Mesia K, Lusakibanza M, Musuamba CT, Apers S, De Bruyne T, Van Miert S, Hermans N, Totté J, Pieters L, Vlietinck AJ: In vitro antiplasmodial activity of callus culture extracts and fractions from fresh apical stems of Phyllanthus niruri L. (Euphorbiaceae): part 2. J Ethnopharmacol 2004, 95:399-404.

15. Ramanandraibe $V$, Grellier P, Martin MT, Deville A, Joyeau R, Ramanitrahasimbola D, Mouray E, Rasoanaivo P, Mambu L: Antiplasmodial phenolic compounds from Piptadenia pervillei. Planta Med 2008, 74:417-421.

16. Addae-Kyereme J, Croft SL, Kendrick H, Wright CW: Antiplasmodial activities of some Ghanaian plants traditionally used for fever/malaria treatment and of some alkaloids isolated from Pleiocarpa mutica; in vivo antimalarial activity of pleiocarpine. J Ethnopharmacol 2001, 76:99-103.

17. Kanokmedhakul S, Kanokmedhakul K, Yodbuddee D, Phonkerd N: New antimalarial bis-dehydroaporphine alkaloids from Polyalthia debilis. J. Nat. Prod. 2003, 66:616-619.

18. de Andrade-Neto VF, Pohlit AM, Pinto AC, Silva EC, Nogueira KL, Melo MR, Henrique MC, Amorim RC, Silva LF, Costa MR, Nunomura RC, Nunomura SM, Alecrim WD, Alecrim MG, Chaves FC, Vieira PP: In vitro inhibition of Plasmodium falciparum by substances isolated from Amazonian antimalarial plants. Mem Inst Oswaldo Cruz 2007, 102:359-365. 
19. Houël E, Bertani S, Bourdy G, Deharo E, Jullian V, Valentin A, Chevalley S, Stien D: Quassinoid constituents of Quassia amara L. leaf herbal tea. Impact on its antimalarial activity and cytotoxicity. J Ethnopharmacol 2009, 126:114-118.

20. Zhang HJ, Tamez PA, Vu DH, Ghee TT, Nguyen VH, Le TX, Le MH, Nguyen MC, Do TT, Soejarto DD, Fong HH, Pezzuto JM: Antimalarial compounds from Rhaphidophora decursiva. J Nat Prod 2001, 64:772-777.

21. He ZD, Ma CY, Tan GT, Sydara K, Tamez P, Southavong B, Bouamanivong S, Soejarto DD, Pezzuto JM, Fong HH, Zhang HJ: Rourinoside and rouremin, antimalarial constituents from Rourea minor. Phytochemistry 2006, 67:1378-1384.

22. Likhitwitayawuid K, Angerhofer CK, Chai H, Pezzuto JM, Cordell GA, Ruangrungsi N: Cytotoxic and antimalarial alkaloids from the tubers of Stephania pierrei. J Nat Prod 1993, 56:1468-1478.

23. Frédérich $M$, De Pauw MC, Llabrès $G$, Tits $M$, Hayette MP, Brandt $V$, Penelle J, De Mol P, Angenot L: New antimalarial and cytotoxic sungucine derivatives from Strychnos icaja roots. Planta Med 2000, 66:262-269.

24. Roumy V, Fabre N, Portet B, Bourdy G, Acebey L, Vigor C, Valentin A, Moulis C: Four anti-protozoal and anti-bacterial compounds from Tapirira guianensis. Phytochemistry 2009, 70:305-311.

25. Muiva LM, Yenesew A, Derese S, Heydenreich M, Peter MG, Akala HM, Eyase F, Waters NC, Mutai C, Keriko JM, Walsh D: Antiplasmodial $\beta$-hydroxydihydrochalcone from seedpods of Tephrosia elata. Phytochem Let 2009, 2:99-102.

26. Henchiri H, Bodo B, Deville A, Dubost L, Zourgui L, Raies A, Grellier P, Mambu L: Sesquiterpenoids from Teucrium ramosissimum. Phytochemistry 2009, 70:1435-1441.

27. Goffin E, Ziemons E, De Mol P, de Madureira Mdo C, Martins AP, da Cunha AP, Philippe $G$, Tits $M$, Angenot $L$, Frédérich $M$ : In vitro antiplasmodial activity of Tithonia diversifolia and identification of its main active constituent: tagitinin C. Planta Med 2002, 68:543-545.

28. Oketch-Rabah HA, Mwangi JW, Lisgarten J, Mberu EK: A new antiplasmodial coumarin from Toddalia asiatica roots. Fitoterapia 2000, 71:636-640.

29. Alves TM, Nagem TJ, de Carvalho LH, Krettli AU, Zani CL: Antiplasmodial triterpene from Vernonia brasiliana. Planta Med 1997, 63:554-555.

30. Ramanandraibe V, Martin MT, Rakotondramanana DL, Mambu L, Ramanitrahasimbola D, Labaïed M, Grellier P, Rasoanaivo P, Frappier F: Pseudoguanolide sesquiterpene lactones from Vernoniopsis caudata and their in vitro antiplasmodial activities. J Nat Prod 2005, 68:800-803.

31. Moon HI, Jung JC, Lee J: Antiplasmodial activity of triterpenoid isolated from whole plants of Viola genus from South Korea. Parasitol Res 2007, 100:641-644.

32. Jullian V, Bourdy G, Georges S, Maurel S, Sauvain M: Validation of use of a traditional antimalarial remedy from French Guiana, Zanthoxylum rhoifolium Lam. J Ethnopharmacol 2006, 106:348-352.

33. Moein MR, Pawar RS, Khan SI, Tekwani BL, Khan IA: Antileishmanial, antiplasmodial and cytotoxic activities of 12,16-dideoxy aegyptinone B from Zhumeria majdae Rech.f. \& Wendelbo. Phytother Res 2008, 22:283-285.

doi:10.1186/1475-2875-10-S1-S5

Cite this article as: Deharo and Ginsburg: Analysis of additivity and synergism in the anti-plasmodial effect of purified compounds from plant extracts. Malaria Journal 2011 10(Suppl 1):S5.

\section{Submit your next manuscript to BioMed Central and take full advantage of:}

- Convenient online submission

- Thorough peer review

- No space constraints or color figure charges

- Immediate publication on acceptance

- Inclusion in PubMed, CAS, Scopus and Google Scholar

- Research which is freely available for redistribution

Submit your manuscript at www.biomedcentral.com/submit
Biomed Central 